IZA DP No. 4604

Repayment versus Investment Conditions and Exclusivity in Lending Contracts

Spiros Bougheas

Indraneel Dasgupta

Oliver Morrissey

November 2009 


\title{
Repayment versus Investment Conditions and Exclusivity in Lending Contracts
}

\author{
Spiros Bougheas \\ University of Nottingham \\ Indraneel Dasgupta \\ University of Durham \\ and IZA \\ Oliver Morrissey \\ University of Nottingham
}

\section{Discussion Paper No. 4604 \\ November 2009}

\author{
IZA \\ P.O. Box 7240 \\ 53072 Bonn \\ Germany \\ Phone: +49-228-3894-0 \\ Fax: +49-228-3894-180 \\ E-mail: iza@iza.org
}

\begin{abstract}
Any opinions expressed here are those of the author(s) and not those of IZA. Research published in this series may include views on policy, but the institute itself takes no institutional policy positions.

The Institute for the Study of Labor (IZA) in Bonn is a local and virtual international research center and a place of communication between science, politics and business. IZA is an independent nonprofit organization supported by Deutsche Post Foundation. The center is associated with the University of Bonn and offers a stimulating research environment through its international network, workshops and conferences, data service, project support, research visits and doctoral program. IZA engages in (i) original and internationally competitive research in all fields of labor economics, (ii) development of policy concepts, and (iii) dissemination of research results and concepts to the interested public.
\end{abstract}

IZA Discussion Papers often represent preliminary work and are circulated to encourage discussion. Citation of such a paper should account for its provisional character. A revised version may be available directly from the author. 
IZA Discussion Paper No. 4604

November 2009

\section{ABSTRACT}

\section{Repayment versus Investment Conditions and Exclusivity in Lending Contracts}

Lenders condition future loans on some index of past performance. Typically, banks condition future loans on repayments of earlier obligations whilst international organizations (official lenders) condition future loans on the implementation of some policy action ('investment'). We build an agency model that accounts for these tendencies. The optimal conditionality contract depends on exclusivity - the likelihood that a borrower who has been denied funds from the original lenders can access funds from other lenders.

JEL Classification: $\quad$ G21, F34

Keywords: long-term loans, investment conditions, repayment conditions, exclusivity

Corresponding author:

Spiros Bougheas

School of Economics

University of Nottingham

University Park

Nottingham, NG7 2RD

United Kingdom

E-mail: spiros.bougheas@nottingham.ac.uk

\footnotetext{
* We would like to thank Daniel Seidmann, Gianni de Fraja and seminar participants at the University of Leicester for helpful comments on an earlier version, and two anonymous referees. The usual caveat applies.
} 


\section{Introduction}

Multi-period financial contracts include clauses that make the availability of future funds conditional on some measure of performance. Conditionality clauses can be grouped into two types: the first type requires borrowers to repay part or in whole any outstanding balances before they receive any new loans while the second type conditions future funds on either some action or the achievement of some performance standard. We will refer to contracts that include the first type as 'conditional on repayment contracts' and to those using the second type as 'conditional on investment contracts'. Conditional on repayment contracts are typically offered by private lenders to businesses and consumers (e.g. loan commitments, credit lines, credit cards, etc.) Private lenders also employ the same type of contract in cases where the ability to command collateral is limited or non-existent, e.g. when directly lending to sovereign states. In contrast, official lenders (to sovereign states), especially International Financial Institutions (IFIs), frequently employ conditional on investment contracts because they have access to some mechanism to enforce or at least monitor compliance with the investment (or policy action) condition or to secure repayment if the condition is not met. It is also common that a group of private borrowers pool their resources (syndicated loans) together to finance a specific project. ${ }^{1}$ These loans, which are similar to the loan agreements provided by IFIs, are divided into tranches where each tranche (finance stage) is conditional on either some performance measure or repayment.

The purpose of this paper is to identify under which circumstances each type of contract is optimal. We suggest that the optimal choice of contract will depend on the ability of a borrower to secure a loan elsewhere if they fail to meet the conditions of a lender. We refer to this as exclusivity: the optimal contract depends on the ability of a lender to deny (exclude) the borrower access to alternative lenders. Although, this is an issue that has been identified as important it has not received sufficient attention. For example, BULLOW and ROGOFF [1989] recognize the absence of other potential lenders as a limitation of their theoretical analysis of sovereign debt contracts. Characteristically, they state that “...the upper bound on any 'reputation' debt is still only the real cost to the country of switching its business to a new set of financial institutions." Similarly, ESTY and MEGGINSON [2003], suggest that by including a

\footnotetext{
${ }^{1}$ See Esty and MegGinson [2003].
} 
large number of lenders, syndicates can credibly pre-commit to a more costly restructuring process and to a larger group of affected banks that will thus be less likely to lend to the same borrower in the future. Lastly, EATON [1990] argues that in the case of sovereign debt other lenders would not provide funds out of fear that the earlier lender would seize payments on future loans. Of course, the last argument is related to the 'seniority' of sovereign debt in relation to other types of debt but there is important distinction in relation to the traditional concept of seniority. Usually the term applies to priority claims in case of bankruptcy. EATON [1990] is referring to the possibility that old sovereign debt obligations might remain senior after the signing of new contracts. In that case, new lenders by being discouraged are 'excluded'. These arguments suggest that IFIs and syndicates, i.e. lenders more closely associated with offering conditional on investment contracts are more able to exclude alternative lenders. In this paper, we offer a theoretical explanation of this tendency.

The notion of analyzing the coexistence of two types of lenders is not in itself new. BELL [1990] provides a model explaining that formal and informal credit markets (lenders) co-exist because they can offer distinct 'packages' combing loan size and interest rate to discriminate between prospective borrowers; whether both continue to coexist and their 'market share' depends on the extent of credit rationing and the ability of a lender to offer an exclusive contract. Whilst appropriate to rural lending, this model does not capture the features of sovereign debt. Specifically, sovereign creditors are distinguished by the type of conditions offered rather than the composition of the loan package, and the possibility of credit rationing is not considered. However, as will be shown, the possibility of official lenders, and for that matter 'syndicated' lenders, offering an exclusive contract is important.

The existing literature (outlined in the next section) tends to treat the two types of conditional financial contracts separately, without addressing how they may relate to each other. ${ }^{2}$ For example there is a literature on sovereign debt concerned with the limits on enforcing repayment, suggesting the need for state-contingent loan contracts including indexation and ex ante renegotiation to align incentives given the debtor's ability to repay; see GROSSMAN and VAN HUYCK [1988], HUBERMAN and KHAN

\footnotetext{
${ }^{2}$ BOUGHEAS, DASGUPTA and MORRISSEY [2007] examine the choice of conditional on investment contracts, as against unconditional contracts, in charitable giving (where repayment is not a feature). They provide an explanation for why donors choose conditional giving, whereas the concern here is with the choice of alternative performance conditions (repayments versus investment).
} 
[1988], SACHS [1988], FROOT, SCHARFSTEIN and STEIN [1989]. In contrast, the literature on 'conditional on investment' lending to sovereign states, especially that on IFI conditionality, has concentrated on the contract design that maximizes the effectiveness of conditionality to overcome adverse selection and moral hazard problems, e.g. DIWAN and RODRIK [1992], FAFCHAMPS [1996], MARCHESI and ThOMAs [1999], FeDERICo [2004] and JeANNe, OSTRY and ZETTELMEYER [2008]. This research does not address the main question of concern here - why different types of lenders choose a different type of contract.

We develop a simple agency model with three types of borrowers, where types are private information. Each type is endowed with a stochastic technology that is available for two consecutive periods. The technology's stochastic return is independently but identically distributed across periods. Two of the three types of borrowers can improve the likelihood of success of their technologies by undertaking an additional type-specific investment, while the third cannot. However, lenders can observe only one type of investment, so the observation does not yield sufficient information to distinguish borrower types. The role of conditionality is to offer incentives to borrowers to use funds for investment rather than consumption. It does so by tying the availability of future funds to some action that the borrower must take; either repaying earlier loans (conditional on repayment contracts) or undertaking the observable investment (conditional on investment contracts). The choice between the two mechanisms depends on the following trade-off. Conditional on investment contracts ensure that, as long as the observable investment is made, future funds will be available independently of the earlier outcomes (project realized returns). However, the observable investment is appropriate for only one type of borrower. In contrast, conditional on repayment contracts ensure that any type will receive future funds, but repayment can only be made when an early repayment is made.

In order for conditionality to work it is paramount that a borrower who has accepted one of the conditional contracts but has been unable to satisfy its conditionality clause, and hence is denied a new loan, does not have access to an alternative source of funds. It is clear that if this is not the case then the incentive mechanism of the contract might break down, hence the contract is not exclusive there is a likelihood of obtaining a loan from another lender. Lenders than can exclude other lenders or who lend to borrowers with circumstances that favour one lender in 
the exclusion of others can place themselves in a stronger position. Private lenders (banks) would not have this ability as they cannot impose any exclusivity. Official lenders such as IFIs or a large group of lenders such as syndicates maybe cannot impose exclusivity but if they can deliver signals on the credibility of a borrower may be able to influence the willingness of private banks to offer loans.

First, we examine the case where having access to other sources of funds is not a concern (exclusivity is assumed). We find that there are three possible outcomes. There is a set of values for the parameters of the model such that it is not optimal to offer any conditional contracts. This is the case when the borrowers who cannot use the extra funds for improving their technology accept a conditional offer and use the funds for consumption. When conditional contracts are feasible it is always optimal to offer the conditional on investment contract. Among the set of parameter values such that conditional contracts are feasible there is a subset where it is optimal to offer a menu of contracts, comprised of the two conditional contracts. It is obvious that the highest level of efficiency is achieved when it is feasible to offer the menu of contracts since it achieves a complete separation of types. We find that it is never optimal to offer only the conditional on repayment contract. The intuition behind the last result is that it is more difficult to separate the type of borrowers that do not have any good use of the extra funds using the repayment contract. This is because with repayment contracts there is a good chance that they will receive funds again but this is not the case with investment contracts.

We then allow for the possibility that those borrowers who have signed a conditional contract but were denied a new loan get access to funds from another source (non-exclusion). Once more, we examine how the optimal contracts offered vary with changes in the parameters of the model. Not surprisingly, we find that if the probability that a borrower denied a new loan can obtain funds from another creditor is sufficiently high then conditional contracts will not be offered. But, more importantly, we also find that conditional on investment contracts are more 'fragile' (more sensitive to exclusivity) than conditional on repayment contracts; there is a range of probabilities where only contracts conditional on repayment will be offered. The intuition behind the result is as follows: for a borrower who uses extra funds for consumption there is still a good chance that they will meet the conditionality clause of the repayment contract, which in turn implies that the expected benefits of having 
access to other borrowers is low. In contrast, the same borrower will never meet the conditionality clause of the investment contract and thus the corresponding benefits are high.

We organize the rest of the paper as follows. In the next section we provide a brief review of some salient literature that examines the optimal design and properties of these two types of conditional financial contracts. In section 3 we develop the model and solve for the optimal mechanism under the supposition that exclusivity is not a concern. In section 4 we introduce non-exclusion and analyze the consequences for mechanism design, in particular the resulting fragile nature of conditional on investment contracts. We offer some final comments in the last section.

\section{Conditional Lending: Related Literature}

The development economics literature on 'conditionality' investigates the rationale for IFI's practice of conditioning loans and future funds on the implementation of some economic reform, and generally relates to the design of conditionality to render it effective in supporting reform (thereby reducing moral hazard and adverse selection). FEDERICO [2004] is representative of this literature, where the focus is on the time inconsistency of conditionality when donors are only able to make imperfect commitments (e.g. the threat to withdraw lending is not credible). ${ }^{3}$ DRAZEN [2002] and PALONI and ZANARDI [2006] consider how conditionality interacts with the political economy of policy reform in borrower countries to assess the effectiveness in inducing reform. The literature does not generally consider a specific choice between repayment and investment conditions. In two papers closely related to our work, SACHS [1989] and RODRIK [1996] argue that the IMF has an advantage over private creditors in enforcing conditional on investment contracts for several reasons, ranging from informational advantages and political neutrality to the ability to control other potential creditors. We provide a formal rationale for the last argument based on exclusivity.

A common rationale offered for IMF conditionality is that it provides incentives to borrowers to use the funds for productive investments, e.g. DIWAN and

\footnotetext{
${ }^{3}$ Note that, in our context, the threat to withhold lending is less credible if alternative lenders exist.
} 
RODRIK [1992], FAFCHAMPS [1996] and MARCHESI and ThOMAS [1999]. ${ }^{4}$ In this respect, our approach is more general because we allow the creditor a wider choice of mechanisms to address the same issue. For example, we find that when non-exclusion is an issue, conditional on investment contracts are not necessarily optimal. MARCHESI and THOMAS [1999] is the most relevant to our work; they also view conditionality on investment as a mechanism that screens high-productivity borrowers from low-productivity ones, although they focus on debt relief issues and do not consider alternative mechanisms.

The existence of alternative lenders imposes some limit on the extent of IFI conditionality, and may even encourage the IFI to tolerate higher levels of noncompliance than would otherwise be the case. PENALVER [2004] notes that sovereign countries have access to private capital markets and this can substitute for IMF borrowing and weaken conditionality (on investment) as our model predicts. Conditional on investment loans may be more attractive to borrowers precisely because there is a possibility of non-compliance without punishment. On the other hand, countries receiving IMF support are also likely to receive either more aid from donors, BIRD and ROWLANDS [2007], or other creditors (see the literature on catalytic finance; e.g. CORSETTI, GUIMARAES and ROUBINI [2006] and MORRIS and SHIN [2006]) because the conditionality is a positive signal of some commitment to policy reform. This implies stronger conditionality, and suggests possible sorting of recipients depending on whether the most viable alternative is private borrowing or aid. From a borrower's perspective, official debt may be preferable to commercial loans because restructuring is likely to be easier.

BOLTON and SCHARFSTEIN [1990] were among the first to consider conditional on repayment contracts. ${ }^{5}$ The difference from our approach is that in their model project returns are not verifiable and thus one period lending is impossible. The conditional contract offers incentives to borrowers to make high payments at the end of the first period in order to receive a new loan in the second period. In our case, the returns are observable but the conditional contracts offer incentives to borrowers to

\footnotetext{
${ }^{4}$ SVENSSON [2000] demonstrates that conditionality (on investment) is only effective if the lender can maintain a commitment to lend only if the conditions are implemented. This requires both that implementation is observable and that the lender's threat not to loan if there is non-compliance is credible, neither of which may hold in practice.

${ }^{5}$ In a general setting, TOWNSEND [1982] recognized that multi-period contracts can mitigate agency problems. WEBB [1991] applied this idea in the design of financial contracts in the presence of adverse selection.
} 
use the extra funds for investment in order to increase the probability that their second period project will be financed. A similar type of mechanism is also considered in the large 'sovereign debt' literature reviewed in EATON and FERNANDEZ [1995].

Lastly, the model is also related to the growing literature on 'group lending' that analyzes the practices of NGOs such as the Grameen Bank in Bangladesh and Sewa in India which use funds from charitable transfers to subsidize lending to poor family groups; GHATAK and GUINNANE [1999], MORDUCH [1999], and more recently RAI and SJÖSTRÖM [2004], provide reviews. The contracts that these organizations offer are a mix of the two types of contracts considered in this paper. In particular, future loans are conditioned on both repayment of earlier loans and on the participation of group members in time-consuming group activities. In addition to problems that inflict typical borrower-lender relationships, these mix contracts are also designed to solve problems that are directly related to group lending (e.g., joint liability rules aim to foster incentives for intra-group monitoring). In contrast, in the present paper we focus exclusively on bilateral financial relationships.

\section{The Model}

There are 2 periods; $t \in\{0,1,2\}$. There is a single good that can be used both for consumption and investment purposes. All agents in the model are risk-neutral and do not discount the future. There is a borrower needs funds to finance a risky project. At $t=0$ the project requires a fixed investment of $K$ units. At $t=1$, if successful, it will yield $X$ units of output and 0 otherwise. The probability of success of the project, $p_{i}\left(E_{j}\right)$, is endogenously determined and it depends on the level of effort $E_{J} \in\{0, e\}$ and type $j \in\{A, B\}$ of an additional investment, and the type $i=\{0,1,2\}$ of the borrower. More specifically,

$$
\begin{aligned}
& p_{0}\left(E_{j}\right)=p_{L} \text { for every } E_{j}, \\
& p_{1}\left(E_{j}\right)=p_{H} \text { for } E_{A}=e \text { and } p_{L} \text { otherwise, and } \\
& p_{2}\left(E_{j}\right)=p_{H} \text { for } E_{B}=e \text { and } p_{L} \text { otherwise. }
\end{aligned}
$$


where $p_{H}>p_{L}$. In words, only type 1 and type 2 borrowers can improve the probability of success of their projects and only by making the appropriate typespecific investment.

The technology is also available at $t=1$, where an investment of $K$ units will yield $X$ units at $t=2$ with the same probability distribution for each type. For either a type 1 or a type 2 borrower who has made the appropriate additional investment in period 0 , the probability of success of the second project remains $p_{\mathrm{H}}$. We also assume that the borrower uses the first period profits (revenues minus repayment), if any, for consumption. Thus, to finance the second period project the borrower needs a new loan.

The borrower can raise funds in competitive financial markets. For simplicity, we assume that the interest rate is equal to zero. Let $\pi_{0}, \pi_{1}$, and $\pi_{2}$ $\left(\pi_{0}+\pi_{1}+\pi_{2}=1\right)$ denote the prior beliefs of lenders about the probability distribution of types 0,1 and 2 respectively. A lender makes a loan offer and the borrower either accepts it or rejects it. If the borrower rejects the offer both parties make zero profits.

For the moment, we consider one-period loans. In this case, the loan offer includes the size of the loan at $t=0$ and the repayment conditional on the success of the project at $t=1$. This last condition implies that the borrower is protected by limited liability. We also impose the following condition on the payoffs which ensures that the additional investments that improve the probability of success of the projects of type 1 and type 2 borrowers are efficient (even in the case of single-period contracts).

Condition 1: $p_{H} X-K-e>p_{L} X-K>0$

Thus, the optimal loan size to either a type 1 or a type 2 borrower is equal to $K+e$. It follows that the repayment will be set equal to $(K+e) / p_{H}$. The optimal loan size for type 0 borrowers is $K$ and the repayment will be set equal to $K / p_{L}$. Under full information the expected return across types over two periods, $Y_{F}$, is given by:

$$
Y_{F}=2 \pi_{0}\left(p_{L} X-K\right)+\left(\pi_{1}+\pi_{2}\right)\left\{2\left(p_{H} X-K\right)-e\right\}
$$

\subsection{One-period Lending under Asymmetric Information}


Now, suppose that types are private information and that only type A investment is observable (it may, for example, relate to acquiring a skill or implementing a specific policy). While lenders can verify that a borrower has made a type A investment they cannot do so for the type B investment (this implies that contractual terms can be only conditioned on the type A investment). Thus, there are two types of informational asymmetries in this model; namely, adverse selection because the borrower's type is not observable and moral hazard because type $\mathrm{B}$ investment is not observable. In addition, we assume that payoffs are observable and contractible.

The following condition implies that if borrower types were observable (so that type 0 borrowers can be excluded) both type 1 and type 2 borrowers would prefer to use the extra funds for investment rather than consumption.

Condition 2: $p_{H} X-K-e>p_{L}\left(X-(K+e) / p_{H}\right)+e$

Thus, when we restrict our attention to one-period contracts the ability to observe the type A investment is inconsequential. The above information restrictions also imply that if lenders offer one-period contracts they must be contracts that pool at least type 1 and type 2 borrowers. Indeed, the following lemma implies that if there exists an equilibrium where lenders are willing to provide one-period loans of size $K+e$, (i.e. where they are willing to finance the additional investment) it must be an equilibrium that pools all three types of borrowers. ${ }^{6}$

\section{Lemma 1: A separating equilibrium does not exist.}

Given that any feasible contract must pool all three types of borrowers, the repayment must be equal to $(K+e) / p^{*}$, where $p^{*}=\pi_{0} p_{L}+\left(1-\pi_{0}\right) p_{H}$. This repayment will be sufficient for lenders to break-even if the following condition, which ensures that type 1 and type 2 borrowers have the incentive to invest instead of consuming the additional funds, is satisfied.

Condition 3: $p_{H}\left(X-(K+e) / p^{*}\right)>p_{L}\left(X-(K+e) / p^{*}\right)+e$

The left-hand side corresponds to the payoff of either a type 1 or a type 2 borrower who uses the funds for the appropriate investment. The right-hand side is equal to the corresponding payoff when the additional funds are used for consumption. When the above condition does not hold lenders will only offer loans of size $K$ with repayment

\footnotetext{
${ }^{6}$ All the proofs are provided in the Appendix.
} 
$K / p_{L}$; i.e. they will not finance the additional investment (conditions 2 and 3 are consistent because $p_{H}>p^{*}$ ). We can summarize the results of this section in the following proposition:

Proposition 1: When $\frac{p_{H}-p_{L}}{p^{*}+p_{H}-p_{L}}<\frac{e}{p^{*} X-K}<1$ the presence of moral hazard and adverse selection imply that one-period contracts cannot achieve the optimal level of investment.

In what follows, we are going to assume that the double inequality stated in Proposition 1 holds so that one-period contracts that allow for the extra investment are not feasible. Still, the underinvestment problem might be mitigated by introducing multi-period contracts.

\subsection{Two-period Contracts Conditional on Investment}

In this section, we consider a lender that is able to make long-term commitments. Given that the technology is also available at $t=1$ and that the type A investment is observable, the lender might be able to improve efficiency by designing a two-period contract where a second loan is made available at $t=1$ under the condition that at $t=0$ the borrower makes the type A investment. For the moment, we assume that a borrower who has accepted a two-period contract and has been denied second period credit can not get access elsewhere to a one-period loan in the second period. ${ }^{7}$

The terms of the contract are the following: At $t=0$ the lender offers a loan of size $K+e$. If the borrower invests the additional funds in a type A investment then the lender provides another loan of size $K$ with repayment equal to $K / p_{H}$ which is conditional on success at $t=2 .^{8}$

\footnotetext{
${ }^{7}$ The commitment not to finance the second period project is not time-consistent. Nevertheless, even if such a commitment might not be credible from private profit maximizing banks, it can be credible if it is made by an IFI. The observation that IFIs are usually repaid (see JEANNE and ZETTLEMEYER [2001] for some evidence related to IMF) is a proof that their commitment is credible.

${ }^{8}$ Notice that competition only implies that the two-period expected return of the lender equals zero and not necessarily that each period's expected profits equal zero. However, given our supposition that the conditionality of the contract cannot be renegotiated setting each period's expected return equal to zero has no consequences.
} 
Let $\Pi_{i}(0)$ denote the two-period payoff of type $i$ borrowers who do not make the additional investment. Notice that all types have the option not to make the additional investment and use a sequence of one-period loans. In that case their payoff will be:

$$
\Pi_{i}(0)=2\left(p_{L} X-K\right)
$$

We assume that the above two-period payoff is higher than the single-period payoff derived when the additional investment is made:

Condition 4: $\Pi_{i}(0)>p_{H} X-K-e$.

If the above condition and Condition 2 are satisfied then all borrowers will prefer to use a sequence of two period contracts rather than using the additional funds of a conditional contract for consumption. Notice that in the latter case they will not be able to invest at $t=1$ as they would have failed to meet the conditionality clause of the contract. We can prove the following results:

Lemma 2: If Conditions 1 and 2 hold then a type 1 borrower will accept a conditional two-period contract and use the funds for investment.

Lemma 3: Condition 2 implies that if a type 2 borrower accepts the conditional contract she will invest the funds in the type $\mathrm{B}$ investment.

We are ready to prove the main result of this section:

Proposition 2: Suppose that Condition 4 is satisfied. Then the conditional contract will be accepted only by type 1 borrowers and the other types will use a sequence of one-period contracts.

Remark 1: When Condition 4 is not satisfied there is an equilibrium where both type 1 and type 2 borrowers receive loans and each type makes the appropriate investment but only type 1 borrowers receive future loans. Of course, if the conditional on investment contract was the only option this would have important implications for the IFIs willingness to provide such contracts which in that case it would probably depend on the relative proportions of types. However, given that the alternative contract fits better the requirements of type 2 borrowers, without any loss of generality, we are going to restrict attention to the case where Condition 4 holds. 
We can now compare the expected return under the conditional contract with the full-information average return. The expected return of the two-period conditional on investment contract $Y_{I}$, is given by:

$$
Y_{I}=\left(\pi_{0}+\pi_{2}\right) 2\left(p_{L} X-K\right)+\pi_{1}\left(2\left(p_{H} X-K\right)-e\right)
$$

Subtracting the above expression from (2) we can estimate the effect of asymmetric information on expected returns as a result of the under-investment by type 2 borrowers.

$$
Y_{F}-Y_{I}=\pi_{2}\left(2\left(p_{H}-p_{L}\right) X-e\right)
$$

The difference is equal to the underinvestment of type 2 borrowers. As they opt out of the conditional on investment contract they do not undertake the type B investment that is optimal for their type.

\subsection{Two-period Contracts Conditional on Repayment}

In this section, we consider a two-period contract, where a second period loan is made available under the condition that the first-period loan is repaid. Again, we assume that other lenders are not willing to offer one-period contracts to those borrowers denied second-period credit from the initial lender.

The terms of the contract are the following: At $t=0$ the lender offers a loan of size $K+e$. If the borrower repays $(K+e) / p_{H}$ at $t=1$, then the lender provides another loan of size $K$ with repayment equal to $K / p_{H}$ which is conditional on success at $t=2$.

A type $k \in\{1,2\}$ borrower's total expected payoff, given that the additional funds are used for investment, $\Pi_{k}(e)$ is equal to:

$$
\Pi_{k}(e)=\left(1+p_{H}\right)\left(p_{H} X-K\right)-e
$$

\footnotetext{
${ }^{9}$ In BOLTON and SCHARFSTEIN [1990] project returns are not verifiable and thus the conditional contract offers incentives to borrowers to make high payments at the end of the first period in order to receive a new loan in the second period. In our case, the returns are observable but the conditional contract offers incentives to borrowers to use the extra funds for investment in order to increase the probability that their second period project will be financed.
} 
In contrast their corresponding expected payoff, when they use the funds for consumption, $\Pi_{k}(0)$, is equal to:

$$
\Pi_{k}(0)=p_{L}\left(X-(K+e) / p_{H}\right)+e+\left(p_{L}\right)^{2}\left(X-K / p_{H}\right)
$$

Notice that, under the supposition that the contract pools type 1 and type 2 borrowers, the appropriate probability for calculating the repayments is $p_{H}$. Expression (7) also corresponds to the total expected profits of a type 0 borrower who pretends to be either a type 1 borrower or a type 2 borrower. If any type of borrower opts to finance her two projects by a sequence of one period loans from private banks then their corresponding payoff, $\Pi_{i}(0)$, is given by (3).

Lemma 4: Suppose that Condition 2 holds. Then, $\Pi_{k}(e)>\Pi_{k}(0)$.

The following proposition states the main result of this section:

Proposition 3: If $\Pi_{k}(e)>\Pi_{i}(0)>\Pi_{k}(0)$ there exists a separating equilibrium where type 1 and 2 borrowers accept conditional contracts and type 0 borrowers receive one-period loans.

Again, we can compare the expected return under the new contract with the full-information optimal average return. The expected return of the two-period contract that is conditional on repayment, $Y_{R}$, is given by:

$$
Y_{R}=\pi_{0} 2\left(p_{L} X-K\right)+\left(\pi_{1}+\pi_{2}\right)\left\{\left(1+p_{H}\right)\left(p_{H} X-K\right)-e\right\}
$$

Subtracting the above expression from (2) we can once more estimate the effect of asymmetric information on expected returns as a result of under-investment.

$$
Y_{F}-Y_{R}=\left(\pi_{1}+\pi_{2}\right)\left\{\left(1-p_{H}\right)\left(p_{H} X-K\right)\right.
$$

Relative to the full information case where type 1 and type 2 borrowers receive new funds with certainty under asymmetric information, where contracts are conditional on repayment they only receive continuation funds with probability $p_{H}$. Thus with the complementary probability there is underinvestment by those types in the second period.

\subsection{The Optimal Choice of Contracts}


We have examined two types of long-term contracts that dominate a sequence of short-term contracts. Both types of long-term contract require the borrower to meet some condition in order to receive future loans. This is necessary in order to separate type 1 and type 2 (productive) borrowers from unproductive type 0 borrowers. One of the long-term contracts conditions the provision of loans in future periods on the use of funds by the borrower. The other long-term contract conditions future loans on the ability of the borrower to make early repayments. What is the appropriate choice of contracts? We have the following trade-off between the two types of long-term contracts. When the contract is conditional on investment type 1 borrowers receive with certainty future loans but type 2 borrowers do not. This is because even if they have made the appropriate investment the latter is not observable. In contrast, when the contract is conditional on repayment both types receive future loans but only if their early projects have been successful. Thus, as has been argued before (see, for example, MARCHESI and THOMAS [1999]) conditional on investment contracts serve better as a screening device. Of course, as the following proposition suggests, there is a third possibility. Lenders can offer a menu of contracts that comprises the two conditional contracts. ${ }^{10}$

Proposition 4: (Optimal choice of contracts) Suppose that those borrowers who received conditional loans and were denied second-period loans cannot receive funds in the second period from other lenders. Then,

a) if $\Pi_{i}(0)<p_{L}\left(X-(K+e) / p^{*}\right)+e$ lenders will not offer any conditional loans,

b) if $p_{L}\left(X-(K+e) / p^{*}\right)+e<\Pi_{i}(0)<\Pi_{k}(0)$ lenders will only offer the contract conditional on investment, and

c) if $\Pi_{k}(0)<\Pi_{i}(0)$ lenders will offer the menu of contracts.

It is clear that expected returns are maximized when the equilibrium with the menu of contracts is feasible since it achieves a complete separation of types. To see this, denote by $Y_{M}$ the expected returns when the menu of contracts is offered. Then,

$$
Y_{M}=\pi_{0} 2\left(p_{L} X-K\right)+\pi_{1}\left(2\left(p_{H} X-K\right)-e\right)+\pi_{2}\left(\left(1+p_{H}\right)\left(p_{H} X-K\right)-e\right)
$$

\footnotetext{
${ }^{10}$ The IMF has been criticized after the East-Asian crisis of 1997 of offering contracts with too stringent performance conditions to that region. Those countries might have been better had they been offered loans with specific repayment schedules without any restructuring requirements; see STIGLITZ [2002].
} 
Once more, by subtracting the above expression from (2) we can estimate the effect of asymmetric information on expected returns as a result of underinvestment.

$$
Y_{F}-Y_{M}=\pi_{2}\left(1-p_{H}\right)\left(p_{H} X-K\right)
$$

When the menu of contracts is feasible and offered, underinvestment only results in the case where the first-period project of type 2 borrowers fails. This is because type 1 borrowers choose the conditional on investment contract, make the type A investment and thus receive another period funding with certainty. In contrast, type 2 borrowers choose the conditional on repayment contracts but when the first period project fails they are denied funds for the second project.

Remark 2 (Correlation of returns): Up to this point, we have restricted our attention to the case where project returns across periods are independently distributed. However, it is straightforward to examine how the optimal contract choice would be affected when we allow the returns to be correlated. When we introduce a positive correlation (the more plausible case) of returns across periods the case for the repayment contract, ceteris paribus, is strengthened. The reason is that under the repayment contract the borrower receives a future loan only when the initial project has been successful. In contrast, under the investment contract a type 1 borrower receives a future loan even if the original project fails.

\section{Fragile Conditionality and Exclusivity}

Now consider the possibility that those borrowers who received conditional loans but were denied second-period loans might now receive funds for their second period projects from other lenders. Let $\theta$ denote the probability of getting these loans. It is clear that this possibility affects the expected payoffs when borrowers receive funds initially. We assume that the type of original loans (conditional on repayment or investment) is observable by other lenders.

We begin the analysis for the case when the loans are conditional on repayment. Suppose that new lenders believe that the borrower had the incentive to invest the extra funds (we will soon demonstrate that these beliefs are consistent with the equilibrium solution). Then, they will set the interest rate at $1 / p_{H}$. In this case the 
new expected payoff for either a type 1 borrower or a type 2 borrower who uses the extra funds for investment, $\Pi_{k}^{*}(e)$, is equal to:

$$
\Pi_{k}^{*}(e)=\Pi_{k}(e)+\theta\left(1-p_{H}\right)\left(p_{H} X-K\right)
$$

For either a type 1 borrower or a type 2 borrower who uses the extra funds for consumption and for a type 0 borrower who pretends to be a type $k \in\{1,2\}$ the corresponding new expected payoff, $\Pi_{k}^{*}(0)$, is:

$$
\Pi_{k}^{*}(0)=\Pi_{k}(0)+\theta\left(1-p_{L}\right) p_{L}\left(X-K / p_{H}\right)
$$

Lemma 5: Suppose that Condition 2 holds. Then $\Pi_{k}^{*}(e)>\Pi_{k}^{*}(0)$.

The lemma implies that, as long as type 0 borrowers do not choose the conditional contract, type 1 and type 2 borrowers will use the extra funds for investment. We therefore need to ensure that type 0 borrowers will not choose the conditional contract. If $\Pi_{k}^{*}(0)>\Pi_{i}(0)$, type 0 borrowers pretend to be one of the other types and choose the conditional contract. Of course, in this case, under the existing arrangement separation of types is not possible and there will be under-investment. The following proposition describes the conditions under which separation fails:

Proposition 5: If $\theta>\frac{\Pi_{i}(0)-\Pi_{k}(0)}{\left(1-p_{L}\right) p_{L}\left(X-K / p_{H}\right)} \equiv \theta^{*}$ then conditional on repayment contracts will not be offered.

The proposition implies that for separation to be feasible the probability of receiving a second period loan from other lenders, given that no funds were made available by the initial lender, cannot be very high.

Next, we consider the case where the loans are conditional on investment. Given that the new lenders know that the original loan was conditional on investment, they know that the borrower has not used the extra funds for investment and so set the interest rate at $1 / p_{L}$. The payoff to a borrower who uses the funds for consumption but, with probability $\theta$, receives a second period loan, is equal to $p_{L}\left(X-(K+e) / p_{H}\right)+e+\theta\left(p_{L} X-K\right) .{ }^{11}$ Once more we can calculate a critical

\footnotetext{
${ }^{11}$ Using the same method of proof as the one used for lemma 6 it is straightforward to show that, as long as type 0 borrowers do not choose the conditional contract, type 1 and type 2 borrowers will not use the extra funds for consumption.
} 
value $\theta^{* *}$ such that the above payoff is equal to the one that corresponds to a sequence of one-period contracts, $\Pi_{i}(0)$.

Proposition 6: If $\theta>\frac{\Pi_{i}(0)-\Pi_{k}(0)}{p_{L} X-K} \equiv \theta^{* *}$ then conditional on investment contracts will not be offered.

Furthermore, comparing the above threshold to the one obtained when the loans are conditional on repayment, we get the following important proposition:

Proposition 7: Loans conditional on investment are more fragile than loans conditional on repayment.

In words, loans conditional on investment are less likely to be offered.

\subsection{The Optimal Choice of Contracts}

As the following proposition demonstrates, fragility can also affect the contracts offered by the international organization.

Proposition 8: (Optimal choice of contracts under fragility) Suppose that those borrowers who received conditional loans and were denied second-period loans, with probability $\theta$ receive funds for their second period projects from new lenders. Then,

a) if $\Pi_{k}(0)>\Pi_{i}(0)>p_{L}\left(X-(K+e) / p^{*}\right)+e$ and $\theta^{* *}>\theta$ only contracts conditional on investment will be offered,

b) if $\Pi_{k}(0)<\Pi_{i}(0)$ and $\theta^{* *}>\theta$ both conditional contracts (menu of contracts) will be offered,

c) if $\Pi_{k}(0)<\Pi_{i}(0)$ and $\theta^{*}>\theta>\theta^{* *}$ only contracts conditional on repayment are feasible.

In all other cases no contract will be offered.

Comparing propositions 4 and 8 we observe that the likelihood of alternative sources of funds can affect the menu of contracts offered by lenders. Our results suggest that one possible explanation for the tendency of international organizations, e.g. IMF and World Bank, to offer conditional on investment contracts is their ability to minimize fragility. 


\section{Concluding Comments}

It is common practice that lenders condition future loans on some performance measure that serves as an indicator of borrowers' creditworthiness. For international lending organizations the implementation of some policy action serves as such an indicator while private lenders, because they either cannot monitor investment conditions of lack the ability to exclude other lenders, rely on the ability of their clients to make repayments. In both cases, lenders need to ensure that their clients are using the loaned funds for their intended purpose. As has already been demonstrated in the literature both types of 'conditionality' can provide a solution to this incentive problem. This paper goes a step further to identify the circumstances under which each type of conditionality is optimal.

One possible explanation is the fragile nature of conditional on investment contracts under non-exclusivity. For conditionality to work, in the kind of environment that we have analyzed, it is paramount that when lenders deny future loans borrowers do not have access to alternative sources of funds. We have demonstrated that the optimal contract offered depends on the ability to exclude access to alternative lenders. When exclusivity is not a major issue, conditional on investment contracts are optimal as they provide better incentives for using loaned funds appropriately. In contrast, when exclusion is not possible conditional on investment contracts are fragile and conditional on repayment contracts are optimal (as they reduce the likelihood of those cases where fragility is an issue). Our results are consistent with RODRIK [1996] who argues that one of the advantages of international organizations over private lenders is their ability to control other lenders. We argue that for the opposite reason private lenders prefer to offer conditional on repayment contracts.

One important issue that we have ignored in order to keep our analysis tractable, and which has recently been addressed in EICHENGREN, KLETZED and MODY [2006], is the role of international organizations and banks as monitors (which they contrast to the lack of monitoring by bondholders); MARCHESI and SABANI [2007] also address the potential conflict arising from the IMF's dual role as a lender and as a monitor. As long as part of the purpose of monitoring by international organizations is to ensure that conditionality is protected by excluding other potential lenders, our results are consistent with theirs. This is clear for international 
organizations (conditional on investment contracts) and bond markets (conditional on repayment contracts). The monitoring role usually attributed to banks is the supervision of the activities of firms when they are under distress (e.g. TOWNSEND [1979] and DIAMOND [1984]) and is not related to fragility; therefore the fact that banks offer conditional on repayment contracts is still consistent with their monitoring activities.

The introduction of 'exclusivity' into our agency model has allowed us to provide a rationale for why international organizations choose to offer conditional on investment contracts (because they have some possibility to exclude other lenders, such contracts are not fragile) while private creditors offer contracts conditional on repayment. Our model also suggests that even in the absence of exclusion a better separation of borrowers might be achieved by offering a menu of contracts. To keep the analysis tractable we have treated 'exclusivity' as an exogenous parameter. A potentially interesting extension of our work would be to endogenize it. One possible way to do so is to follow the SHARPE [1990] customer relationships model where in the process of lending a creditor learns more than others about its own customers. This has a natural corollary with IFIs such as the IMF who do have more information about sovereign borrowers than do private lenders. Another possible extension is empirical, to examine the extent to which international organizations can exclude other lenders. The empirical literature suggesting that the IMF has a catalytic effect, by providing a signal of creditworthiness that encourages other lenders to offer loans (e.g. BIRD and ROWLANDS [2007]), is not necessarily inconsistent with our model as it is contingent on timing. To the extent that the IMF can exclude other lenders it is optimal to offer conditional on investment contracts but, once the actions have been implemented, it may then be optimal for other lenders to enter.

\section{Appendix}

Proof of Lemma 1: We show that a type 0 borrower will always pretend to be either a type 1 or a type 2 . The payoff of a type 0 borrower who pretends to be either a type 1 or a type 2 borrower and uses the additional investment funds for consumption is: $p_{L}\left(X-(K+e) / p_{H}\right)+e$. The payoff when he truthfully reveals his type is: $p_{L} X-K$.Since, $p_{H}>p_{L}$ the first expression is always larger. 
Proof of Proposition 1: The violation of Condition 3 implies the first inequality. The second inequality implies that adverse selection alone is not sufficient for underinvestment.

Proof of Lemma 2: Condition 1 implies that a type 1 borrower prefers to accept the conditional loan and make the type A investment to the sequence of one-period contracts. Condition 2 implies that a type 1 borrower also prefers the first alternative to accepting the two-period contract but using the funds for consumption. By using the funds for consumption they will be giving up the second period profits as they will not be granted a second period loan.

Proof of Lemma 3: Condition 2 implies that a type 2 borrower who asks for additional funds will not use them for consumption. Furthermore, the borrower would never use these funds for a type A investment because it does not improve the probability of success of the project and consequently the funds are wasted. The only thing that the borrower gains by a type A investment is a loan in the following period but the same outcome can be achieved by opting for a sequence of one-period contracts.

Proof of Proposition 2: It follows immediately from Lemmas 2 and 3.

Proof of Lemma 4: It follows immediately from the fact that $p_{H}>p_{L}$.

Proof of Proposition 3: $\Pi_{k}(e)>\Pi_{i}(0)$ implies that type 1 and 2 borrowers will prefer to seek funds from lenders offering the conditional contract and use the extra funds in the first period to improve the quality of their projects. $\Pi_{i}(0)>\Pi_{k}(0)$ implies that type 0 borrowers will truthfully reveal their types by financing their projects through the private banking system with a sequence of one period loans.

Proof of Proposition 4: The proposition follows from Propositions 2 and 3 and the inequality $\Pi_{k}(0)>p_{L}\left(X-(K+e) / p^{*}\right)+e$.

Proof of Lemma 5: As long as $p_{H}\left(1-p_{H}\right) \geq p_{L}\left(1-p_{L}\right)$ the inequality follows from Lemma 4. Then, suppose that $p_{H}\left(1-p_{H}\right)<p_{L}\left(1-p_{L}\right)$. It is clear that it suffices to show that the inequality holds for $\theta=1$. When $\theta=1, \Pi_{k}^{*}(e)$ equals $2\left(p_{H} X-K\right)-e$ 
while $\Pi_{k}^{*}(0)$ equals $2 p_{L}\left(X-(K+e) / p_{H}\right)+e$. Once more the inequality follows from Lemma 2.

Proof of Proposition 7: It follows directly from $\theta^{* *}<\theta^{*}$.

Proof of Proposition 8: The proposition follows from propositions 4 and 7. When case (a) holds then conditional contracts cannot achieve any separation even in the absence of fragility. In case (b) conditional on investment contracts would be feasible in the absence of alternative lenders but not so in their presence and therefore no type of contract is offered. In case (c) once more only conditional contracts on investment are feasible but now they are not fragile. In case (d) both contracts are feasible and neither is fragile: as a result the menu of contracts is offered that achieves complete separation. In case (e) both contracts are feasible in the absence of alternative lenders but the contract conditional on investment is not in their presence and thus only the contract conditional on repayment is offered. Finally, in case (f) even if both conditional contacts are feasible in the absence of alternative lenders, no contract is offered.

\section{References}

BELL, C. [1990], "Interactions Between Institutional and Informal Credit Agencies in Rural India," World Bank Economic Review, 4, 297-328.

BIRD, G., AND D. ROWLANDS [2007], "The IMF and the Mobilisation of Foreign Aid," Journal of Development Studies, 43, 856-870.

Bolton, P., AND D. Scharfstein [1990], “A Theory of Predation Based on Agency Problems in Financial Contracting," American Economic Review 80, 93-106.

Bougheas, S., I. DAsgupta AND O. MORRISSEY [2007], "Tough Love or Unconditional Charity?" Oxford Economic Papers 59, 561-582.

Bullow, J. AND K. RogofF [1989], "Sovereign Debt: Is to Forgive to Forget?" American Economic Review 79, 43-50.

CORSETti, G., B. GUIMARAES AND N. RoubINI [2006], International Lending of Last Resort and Moral Hazard: A Model of IMF's Catalytic Finance," Journal of Monetary Economics 53, 441-471.

DiAMOND, D. [1984], "Financial Intermediaries and Delegated Monitoring," Review of Economic Studies 51, 393-414.

DiWAN, I., AND D. RODRIK [1992], "External Debt, Adjustment, and Burden Sharing: A Unified Framework," Princeton Studies in International Finance No 73, Princeton University. 
DrAZEN, A. [2002], "Conditionality and Ownership in IMF Lending: A Political Economy Approach," IMF Staff Papers, 49, 36-67.

EATON, J. [1990], "Debt Relief and the International Enforcement of Loan Contracts," Journal of Economic Perspectives 4, 43-56.

EATON, J. AND R. FERNANDEZ [1995], "Sovereign Debt,” pp. 2031-2079 in: G. Grossman and K. Rogoff (eds.), Handbook of International Economics, Vol. 3, North Holland, Amsterdam.

Eichengreen, B., K. KLetzer and A. Mody [2006], "The IMF in a World of Private Capital Markets," Journal of Banking and Finance 30, 1335-1357.

ESTY, B., AND W. MeGGInson [2003], "Creditor Rights, Enforcement, and Debt Ownership Structure: Evidence from the Global Syndicated Loan Market," Journal of Financial and Quantitative Analysis 38, 37-59.

FAFCHAMPS, M. [1996], "Sovereign Debt, Structural Adjustment and Conditionality," Journal of Development Economics 50, 313-335.

FEDERICO, G. [2004], “Aid and Policies under Weak Donor Conditionality,” Journal of African Economies, 13, 395-416.

Froot, K., D. ScharfsteIn and J. STEIN [1989], "LDC Debt: Forgiveness, Indexation, and Investment Incentives," Journal of Finance 44, 1335-1350.

Grossman, H., AND J. VAN HUYCK [1988], "Sovereign Debt as a Contingent Claim: Excusable Default, Repudiation, and Reputation," American Economic Review 78, 1088-1097.

GHATAK, M., AND T. GuinNANE [1999], "The Economics of Lending with Joint Liability: A Review of Theory and Practice," Journal of Development Economics 60, 195-228.

HuBERMAN, G., AND C. KAHN [1988], "Limited Contract Enforcement and Strategic Renegotiation," American Economic Review 78, 471-484.

JEANNE, O., J. OSTRY AND J. ZETTELMEYER [2008], "A Theory of International Crisis Lending and IMF Conditionality,” IMF Working Paper No. 216, Washington.

JeAnNe, O., AND J. ZeTtelmeyer [2001], "International Bailouts, Moral Hazard, and Conditionality," Economic Policy 33, 409-432.

MARCHESI, S., AND L. SABANI [2007], "IMF Concern for Reputation and Conditional Lending Failure: Theory and Empirics", Journal of Development Economics, 84, 640-666.

MARCHESI, S., AND J. THOMAS [1999], "IMF Conditionality as a Screening Device," Economic Journal 109, C111-C125.

MoRDUCH, J. [1999], “The Microfinance Promise," Journal of Economic Literature $37,1569-1614$.

MORRIS, S., AND H. SHIN [2006], “Catalytic Finance: When Does it Work?” Journal of International Economics 70, 161-177.

PALONI, A., AND M. ZANARDI 2006, "Can conditionality improve borrower ownership," pp. 292-311 in: A. Paloni and M. Zanardi (eds), The IMF, World Bank and Policy Reform, Routledge, London. 
Penalver, A. [2004], "How Can the IMF Catalyze Private Capital Flows? A Model", Bank of England Working Paper 215, Bank of England, London.

RAI, A., AND T. SJÖSTRÖM [2004], "Is Grameen Lending Efficient? Repayment Incentives and Insurance in Village Economies," Review of Economic Studies 71, 217-234.

RODRIK, D. [1996], "Why is There Multilateral Lending?" in M. Bruno and B. Pleskovic (eds.) Proceedings of the World Bank Conference on Development Economics 1995, World Bank, Washington.

SACHS, J. [1988], "Conditionality, Debt Relief, and the Developing Country Debt Crisis," National Bureau of Economic Research: Working Paper Series No. 2644, Boston.

SACHS, J. [1989], "Conditionality, Debt Relief and the Development Country Debt Crisis,” pp. 255-296 in: J. Sachs (ed.) Developing Country Debt and Economic Performance: the International Financial System, vol.l, Chicago University Press, Chicago.

SHARPE, S. [1990], “Asymmetric Information, Bank Lending, and Implicit Contracts: A Stylized Model of Customer Relationships," Journal of Finance 45, 10691087.

StIGLITZ, J. [2002], Globalization and its Discontents, Norton, Washington.

Svensson, J. [2000], "When is Foreign Aid Policy Credible: Aid Dependence and Conditionality," Journal of Development Economics, 61, 61-84.

TownSEND, R. [1979], "Optimal Contracts and Competitive Markets with Costly State Verification," Journal of Economic Theory 21, 265-293.

TOWNSEND, R. [1982], "Optimal Multiperiod Contracts and the Gain from Enduring Relationships under Private Information," Journal of Political Economy 90, $1166-1186$

WeBB, D. [1991], "Long-term Financial Contracts Can Mitigate the Adverse Selection Problem in Project Financing," International Economic Review 32, 305-320.

Spiros Bougheas, School of Economics, University of Nottingham, University Park, Nottingham, NG7 2RD, United Kingdom; e-mail spiros.boughas@nottingham.ac.uk

Indraneel Dasgupta, Durham Business School, Durham University, Mill Hill Lane, Durham DH1 3LB, United Kingdom; e-mail indraneel.dasgupta@durham.ac.uk

Oliver Morrissey, School of Economics, University of Nottingham, University Park, Nottingham, NG7 2RD, United Kingdom; e-mail oliver.morrissey@nottingham.ac.uk 